\title{
Pakistan's Policy Postures towards Shanghai Cooperation Organization (SCO): An Analysis
}

\author{
Dr. Tauqeer Hussain Sargana ${ }^{1}$, Dr. Mujahid Hussain Sargana ${ }^{2}$, Asim Muneeb Khan ${ }^{3}$, Ms. \\ Latafat Aziz ${ }^{4}$, Dr. Zaheer Abbas ${ }^{5}$ Amna Afzaal ${ }^{6}$ \\ ${ }^{1}$ Assistant Professor, Department of Politics and International Relations, International Islamic \\ University Islamabad (IIUI), Pakistan. tauqeer_taki@yahoo.com \\ ${ }^{2}$ Assistant Professor, Department of Humanities \& Social Sciences, Bahria University Islamabad, \\ Pakistan. mhussain.buic@bahria.edu.pk \\ ${ }^{3}$ Senior Lecturer, Department of Humanities \& Social Sciences,Bahria University Islamabad, \\ Pakistan. amuneeb.buic@bahria.edu.pk \\ ${ }^{4}$ Senior Lecturer, Department of Humanities \& Social Sciences, Bahria University Islamabad, \\ Pakistan. latafat.buic@bahria.edu.pk \\ ${ }^{5}$ Department of Sociology, International Islamic University Islamabad, Pakistan \\ sociologistiiui@gmail.com \\ ${ }^{6}$ PMAS-Arid Agriculture University Rawalpindi, Pakistan \\ amnaafzaal89@gmail.com
}

\section{ABSTRACT}

In 2018 Pakistan as well as India participated for the first time as a full scale member of Shanghai Cooperation Organization (SCO) that held at Qingdao city of China on June 9-10. Obviously, that provided a brilliant opportunity to show willingness and readiness to contribute to the effectiveness of the SCO. Pakistan's inclusion into the organization has opened a timely opportunity to bid for regional peace and economic prosperity for its nation. There are multiple arrangements which help Pakistan to come in the streamline as well as allow the Muslim state to support ongoing priority interests of the organization. Due to Pakistan's membership many changes are expected in the domestic legislation and international commitments generated out of organizational common interest. Moreover, it will have great impact (but positive) on Islamabad's traditional behavior towards regional and international politics particularly on the front of its foreign policy. This article makes the point that among many opportunities that Pakistan's inclusion into SCO brings, there are few challenges for the country as well. For example, inclusion of Pakistan in the SCO is not an isolated decision; India was also given the full membership to join the organization as a permanent member. Traditionally, both Pakistan and India have zero tolerance for each other when it comes to their national security dynamics. Other than United Nations and SAARC, SCO is the third organization where both countries will be sitting together, though UN is quite a different one. Likewise, SAARC, if both the countries maintain the same status-quo of bashing each other, the very purpose of SCO will go in vain. Also, this article proposes that Pakistan shall not be allowed to label itself as a negative factor in the SCO. Therefore, this research paper has shed light on Pakistan's previous inability to benefit from regional organizations while suggesting a way forward for her engagement with the SCO. Believing on the great potential of Pakistan and SCO, this paper has adopted deductive methodology with that of 'economics defines politics' as a conceptual framework.

KeyWords: Shanghai Cooperation Organization (SCO), Regional Anti-Terrorist Structure (RATS), CPEC, OBOR, Kashmir, China, Pakistan, India, Russia 


\section{Introduction:}

The very spirit of the international politics is to create opportunities for global community to better serve humanity and establish the foundations for long lasting peace and prosperity between nations. This is true when we look around and measure developments in the field of trade, business, economics, politics, human development, education, science and technology. Global consensus on international institutions and commitment to uphold the manifestos of such organizations is again a fruitful learning that satisfies the conduct of international politics. Conflicts are obvious so did their impact on politics. Therefore, the emergence of European Union which had rooted out the variability of conflict and brought positive peace among regional states shall be considered remedy to confrontations. Moreover, organizations like ASEAN and many others brought the successful interaction among nations to discuss and merge their vision towards collective politics, progress, peace and prosperity. Hence, it is pertinent to accept the role of regional organizations in bringing positive changes in the relationship of states which are now more convenient for greater cooperation and less prone to conflict.

The original mandate of the organization when it was known as 'The Shanghai Five' had to strengthen mutual trust and disarmament in the five member states that included the border regions of Kyrgyzstan, Kazakhstan, Tajikistan, China and Russia. Starting form issues of mutual trust, the organization enhanced its mandate to cooperate on countering terrorism, extremism and separatism particularly in Central Asia. They nexus of five-member organization in 2006 furthered their commitment to fight against the menace of drug mafia. This was complimented with its role to actively pursue member states interests in Afghanistan, when in 2008 they have announced to play their role in stability of Afghanistan. During the years, the organization have remained resilient to achieve economic interests of each member state. For example, within two years of its emancipation, the five member states of the organization had signed in September 2003 signed a 20 years based Program of Multilateral Trade and Economic Cooperation. As the official website of the Russia's Presidency states that "its longterm goal is the creation of a free trade zone in the SCO space, while favorable conditions for trade and investment are to be promoted in the short-term perspective". These were the basic purposes of creating the organization. If the primary objectives of countering terrorism, extremism and separatism are kept in mind, both Pakistan and India can accrue maximum benefits from the organization.

\section{Understanding} 'Dilemma of Alliances':

Pakistan has not gained a very good experience out of her regional or international memberships. The country has been a victim to regional-cum-international frameworks rather a beneficiary. For example, Pakistan's membership into SEATO and CENTO in September 1954 and September 1955 respectively proved to isolate Pakistan rather exposed its image as an economic paradise. Though, Pakistan joined the so-called organizations due to Indian aggressive designs against its territorial integrity but the very idea of the two organizations was containment of the former Soviet Communism. Pakistan was never interested to contain Soviet Union rather its national security complexities inevitably pushed the leadership to indulge into Western alliance. The end result caused isolation from the Muslim World; distance from the neutral countries particularly NonAligned Movement (NAM), and above all an animosity of the Soviet Union. In 1962 when India and China got into border conflict and war erupted, the US and western states particularly UK and France sold weapons to India. As compared to Pakistan, India did not pay any price to receive massive military support from the US and its allies in Europe. Pakistan did protest with newly elected US leadership on 
Washington's tilt in South Asia but of no use (Jabeen \& Mazhar, 2011).

This installed a new behavior in Pakistan's foreign policy which saw a transition in its approach of international relations. The country got experience of bitter learning and initiated a new chapter of foreign relations with Soviet Union and China. During 1960s, when the Soviet and Chinese were going through political divergences, Pakistan stayed neutral and did not wanted to become party to any side. Unfortunately, in 1969 the Soviet Union leadership introduced a treaty called Asian Collective Security Treaty and wanted Pakistan to join it. The treaty was in fact an arrangement to isolate and contain rising Chinese influence in the region. Pakistan categorically denied such a Soviet move against China, which annoyed Moscow. Pakistan was the only Asian country that had cordial and politically impressive relations with Beijing. India due to 1962 border war does not cherish cordial relations rather was willing to take any step forward to isolate and negate Chinese influence in the region (Khoo, 2011).

Negation of the treaty by Pakistan indirectly failed the Soviet ambitions to isolate China. Once again this came at a cost. In August 1971, India and Soviet Union signed a Treaty of Friendship and Cooperation. In October 1971, New Delhi invoked article 9 of the treaty to seek Soviet support in the backdrop of her actions in East Pakistan, where it was sponsoring terrorists of 'Mukti Bahni'. Pakistan army did a marvelous job to defeat the insurgents but due to Indian actions of 'no fly zone' and diplomatic hustles, failed Pakistan to ensure political, economic, military, and diplomatic backup to forces fighting in East Pakistan. Knowing the professional success of Pakistan army against 'Mukti Bahni', Indian government decided to send its army to backup the insurgents. Due to 'no fly zone' Pakistan remained unable to reinforce its support. In the meanwhile, Pakistan was using all diplomatic channels to invoke international law against Indian military intervention. In this regard on December 05,
1971, Pakistan submitted a ceasefire resolution which was 'vetoed' by the former Soviet Union. On December 06, 1971, Pakistan submitted another resolution for ceasefire, it was again 'vetoed' by former Soviet Union. Once again on December 13, 1971, Pakistan submitted a third resolution for ceasefire but unfortunately it was again 'vetoed' by the former Soviet Union. This gave quite an ideal timeframe for Indian military to fully mobilize its forces in East Pakistan and while shoulder to shoulder getting into the cover of insurgents, New Delhi successfully controlled the choke points (Hilali, 2017).

Pakistan at many occasions ended as a failure when it became part of an alliance or regretted to become. Same happed when once again Pakistan ended in an alliance of the United States during 1980s against the Soviet Union, when Moscow intervened in Afghanistan. Pakistan has done so much to ensure its territorial integrity (Hilali, 2017). It used Organization of Islamic Countries (OIC) to solve Kashmir issue but ended as a failure. In context to Islamic ideology, the country even did not recognized Israel in the backdrop of Palestinian issue but again the Muslim world stayed unmoved on Kashmir. The primary responsible organization to help resolve the Kashmir issue is United Nations, which again carries history of a terrible failure to fulfill its commitments with people of Kashmir. South Asian Association of Regional Cooperation (SAARC) is another failure when it comes to convince India that regional prosperity and progress lies in solving the bilateral issues.

Moreover, the so-called stakeholders of peace like the European Union and the United States of America are more interested in bilateralism rather internationalism of politics. They see Pakistan as a product which could satisfy their lust of political interests, due to which Pakistan has always faced crisis. No other country in the inventory of US foreign relations would top other than Pakistan that has contributed the most to help the American nation protect their interests, 
whether it was Cold War or post 9/11 discourse of war against terrorism. It is Pakistan's ultimate success that the country is now independently dealing with both internal and external challenges posing direct or indirect threats to its national security. It's readiness to deal with conventional and sub-conventional warfare makes her unique bidder of peace and prosperity in the region particularly and at the international level generally. Through all these rigorous challenges which erupted out of international alliances during $20^{\text {th }}$ century and particularly in the aftermath of $9 / 11$ episode, Pakistan got the capability to engage with the doomsday. The price of upholding the slogan of peace for its nation came at a huge price. This is what its forefathers wished and wanted to achieve.

\section{Pakistan and the Shanghai Cooperation Organization:}

History passes but experiences and bitter learning stays intact. It is the nation which through its resolve heals the wounds. Had Pakistan learned from its history? Time will testify but as a keen observer, one can only point out the diplomatic misery that brought even more challenges than opportunities for national security of Pakistan. The dilemma shall not become the fate of its future. That is why it is important to learn from history, the same very way its traditional competitor, the former Soviet Union being today's Russian Federation has learned and modified its foreign policy towards Pakistan. China, Russia, and Pakistan all have had bitter experiences from their history (Ayaz, 2017). Pakistan lost East Pakistan so did the Soviet lost Central Asia. China along with its troubled waters of South China Sea, instable political regimes like North Korea, border dispute with India, issues of containment arising due to US Asia Pivot policy, and lingering Taiwan issue; has developed marvelous resilience against the so-called challenges to its national security. Why not this split resilience shall be merged into collective resilience?

Shanghai Cooperation Organization (SCO) is one of its kinds when the above question comes into discussion. The organization was initially developed to mark security as a common feature of founding member states but with the passage of time acknowledged the prospects of economics and mutual cooperation on multiple domains, made it a body of collectiveness. In 2017, Pakistan successfully was given a permanent membership of the organization which earlier cherished its role as an observer (Dawn, 2017).

In June 2018 Pakistan as well as India participated for the first time in SCO meeting in China as a full scale member of this powerful organization (Pakistan Today, 2018). Obviously this provides a brilliant opportunity to show willingness and readiness to contribute to the effectiveness of SCO. There are several ways to produce a good image of a responsible member. It is time not to repeat the same very old mistakes that Pakistani policy makers traditionally have been practicing. For example, Pakistan joined and separated from many alliances based on its national security priorities, which in findings of this study was never a good move. Pakistan's international or regional alliances shall be orchestrated around economic benefits, whereas the national security needs shall be managed indigenously. Beggars are not choosers neither they uphold respect in a community of developed nations. Pakistan's respect is purely dependent on its ability to ensure territorial integrity through its own resources and technology necessary to induce the immunity of defense against internal and external threats. Moreover, Pakistan's prosperity is solely dependent on its extension towards the world to seek economic alliances based on convergences particularly with Russia and China.

As mentioned earlier, Pakistan has completely addressed its foreign reliance on military procurement by developing its domestic heavy industries that today have addressed more than $80 \%$ security needs (Financial Times Report, 2018). Pakistan armed forces have successfully managed the menace of non-kinetic warfare which includes sub-conventional war, guerilla war, insurgency, cyber war, information war, and 
espionage. All many domains of internal and external pressures including subconventional, conventional and strategic postures are in control of Pakistan (Sharaf, 2017). Manipulation at any of these domains is quite a challenge for the opponents. But the problem is its economic situation that further aggravates diplomatic posturing of Pakistan. Reliance on foreign aid and export fixation to the western countries has clutched the independent posture of Pakistan's foreign policy.

Pakistan's membership in SCO allows her to weaken such clutches while opening up new avenues of economic cooperation with the member states including India. The optimum benefits of the organization can only be extracted if Pakistan does not repeat the same very mistakes that it had earlier attached with different organizations. Regardless of blaming India as harbor of terrorism in Pakistan, Islamabad should engage productively in the SCO anti-terror network, the Regional Anti-Terrorist Structures (RATS) and help establish such a system that could denounce the very negative ambitions of New Delhi. The strategic community of Pakistan is familiar with the fact that blaming has never helped Pakistan but through international and regional instruments, a great deal of comfort had been achieved and would be the only viable tool in future. Therefore, Pakistan should be positive about SCO setup in terms of economic integration while forgetting about India as a bullying neighbor. This would help Pakistan receive greater respect and acknowledgement on her serious approach towards the mission of the organization (Ahsen, 2017).

Engaging India is the best punishment for New Delhi rather denouncing its presence. And of course, that does not mean forgetting Kashmir issue or putting it aside as a matter of bilateral relations with India. Pakistan's case on Kashmir is getting stronger day by day as its foundations are based on United Nations resolutions. International law and norms are at stake if Kashmir issue goes in vain. That is why it is beneficial for Pakistan not to make SCO a body of incorrect political scoring and there will be a time when this platform could so conveniently help Islamabad to project and protect Kashmir.

\section{Indian Gambling on SCO:}

India is taking a unique route towards economic development which only admires herself as a player, benefiter and leader of the whole. It had not learned to get along with others. Hypothetically, if there are hundred striving to achieve an objective good for all, one would find India standing alone at a side while announcing that 'I got a problem and reservations. Such confusion is born out of its domestic political order that has prematurely overstretched mantra of regional hegemon and bidder of a global order. Considering the joint communiqué issued at the end of the April 24, 2018 meeting that included SCO members such as Russia, Pakistan, Kazakhstan, Kyrgyzstan, Tajikistan, and Uzbekistan, who "reaffirmed support" for the Belt and Road Plan of China but it was only India, which got 'problem and reservation' (Blanchard, 2018).

Pakistan needs to learn from her confused and ill-calculated neighbor. While riding on the back of $\mathrm{SCO}$, the region is running towards progress and development but New Delhi with its cunning and politics of anti-regionalism has seen only problems. It also stayed away from an earlier forum on 'the Belt and Road Forum' organized in Beijing, which was attended by 29 heads of state and government, and representatives of 101 other countries. The US\$57 billion worth of CPEC project and its extension as 'One Belt One Road' initiative is the future of Asia in particular and world at large. Staying away and not benefitting from it will be an utter non-sense.

On the other hand, India's involvement in the Chabahar Port development, India-Myanmar-Thailand highway, Bangladesh-Bhutan-India-Nepal initiative and the International North-South Transport Corridor has not been labeled as a 'problem nor an issue of reservations' by 
any of the SCO member states along with OBOR partners. China has been even enthusiastic to extend its economic-cuminfrastructural network towards South Asia as is prevalent from Chinese agreements with Nepal and Sri Lanka, to build connectivity infrastructure. It's only the Indian stalwarts, who even see 'problems and reservations' into such Chinese efforts to rope in other South Asian countries. Pakistan is no exception to such Indian problems and reservations. It only feels 'no problem and no reservation' when Pakistan is clutched into terror, instability, chaos, anarchy, economic strangulation, insurgency, and revolts that being neighbor New Delhi supports. If any chance of coming out from all the above problems is visible, then Indian mantra against Pakistan comes at the surface even it has to denounce CPEC and OBOR.

It is important to remind that in April 2018, two days side-lined bilateral meeting between Indian Prime Minister and Chinese President had no other purpose then to isolate Pakistan (Dawn, 2018). Beijing's commitment is undoubtedly positive and without any negative exploitations. That is why Pakistan had been openly cherishing CPEC and OBOR while using all resources to help achieve the economic bid of its Chinese partners. It is believed that Beijing is not going to change its position on India's bid to join the Nuclear Suppliers Group nor it would buy any Indian proposal to isolate Pakistan while accommodating Indian narrative of terrorism. Moreover, Chinese concerns over Indian participation in antiChina schemes such as the Quad and the Free and Open Indo-Pacific Strategy will be out of negotiation from New Delhi. The socalled confidence building efforts as an 'honest dialogue' could only bring fruitful results for India, if it lowers her reliance on the United States and comes out for the greater acceptance of CPEC and OBOR. Shanghai Cooperation Organization (SCO) has lot to do and Indian fixation with the status quo of its politics is not going to help her nor its old-strategic partners like Russia would be able to help New Delhi. China got strong portfolio. It's the Indian politics that has to come out of its 'black whole' or the dominance of United States over its foreign policy will ensure India ends into 'black whole'.

During the April 2018 SCO Foreign Ministerial meeting, the Indian External Affairs Minister Sushma Swaraj said that "terrorism is an enemy of the basic human rights and the fight against it should also identify States that encourage, support and finance the menace and provide sanctuary to terror groups" (Economic Times, 2018). If Pakistan has to bring terrorism into SCO forum just like the way India does then it must support Indian bid to expose terrorism networks based on Sushma Swaraj official wish (The Hindu, 2018). Pakistan must have responded back to Sushma Swaraj who misrepresented the facts around human rights and terrorism. The Indian External Affairs minister highlighted the following points in her statement:

\section{a. "Terrorism is an enemy of basic human rights".}

Without any doubt, it is. The use of state force such as deployment of more than 1 million Indian troops in Kashmir to suppress people's voice is violation of the basic rights. Use of pellet guns and making thousands of youth permanently blind and irreparable eyes is again violation of basic rights (Saud, 2018). Rapping young girls like 'Asifa Bano' being innocent souls only to remind the Muslims of Kashmir that 'Hindutva Ideology' is their only future. Killing Kashmiri PhD scholars has nothing to do with basic rights rather it is politics of aggression which Indian stalwarts while sitting in New Delhi has crafted for Kashmir (Khuaja, 2018) . Starting from January 1989 till December 2018, the brutality of the Indian military and insanity of the New Delhi's politics altogether had killed 95,265 innocent Kashmiris demanding their fundamental 'right of self-determination'. 


\begin{tabular}{|l|l|}
\hline (From Jan 1989 till Dec 31, 2018) & \\
\hline Total Killings $*$ & 95,265 \\
\hline Custodial Killings & 7,120 \\
\hline Civilian arrested & 145,504 \\
\hline Structures Arsoned/Destroyed & 109,201 \\
\hline Women Widowed & 22,896 \\
\hline Children Orphaned & 107,754 \\
\hline Women gang-raped / Molested & 11,111 \\
\hline
\end{tabular}

Source: Kashmir Media Service (KMS News, 2019)

It was the then Indian Prime Minister and founding father of the Hindu nation, Jawaharlal Nehru, who accepted the United Nations resolution and promised in the United Nations to ensure 'right of selfdetermination' to Kashmiri nation. Denying that very promise by India is again violation of the human rights. Denying the fundamental rights to Kashmiri along with Tamils, Sikhs, and many other minorities is an exposure of incompetence within India. Not fulfilling the rights guaranteed by the international law and Indian own father of the nation, could not give glory to the Indian claims, which Sushma Swaraj chanted during the Foreign Ministerial Meeting in April 2018.

b. In her statement, she also said that, "the fight against terrorism should also indentify states that encourage, finance, and provide sanctuary to terror groups".

Well, on this point the SCO foreign ministers in particular but heads of states in general needs to know certain undeniable facts. It was 1971, when India trained a terrorist outfit 'Mukti Bahni' under the auspices of insurgency and installed them in the then 'East Pakistan' (now Bangladesh) to fight against Pakistan. It was India that after witnessing the failure of its 'Mukti Bahni' terrorists, deployed her standing army in the sovereign territory of Pakistan (the then East Pakistan) at a time when Pakistan followed peaceful co-existence with all its neighbors. India not only trained terrorists but also fueled it in the region. Capture of Kalbushan Yadev, who is a serving Indian Naval Commander is very recent example of its dual face. Being Indian intelligence spy, Yadev trained and financed many insurgent and terrorist groups in Pakistan to sabotage internal peace and ongoing economic projects like CPEC. It was again an Indian serving army officer Col. Purohit who back in 2007 manifested Samjhauta Express terror attack that killed many Pakistanis. It is India who in Karachi to Quetta is fueling insurgency and internal disorder through its agents. It's again India which is using Afghanistan's sovereign territory against Pakistan to support insurgency in FATA, Baluchistan, and Karachi. India is not innocent at all. The confession of Tehrek-e-Taliban Pakistan (TTP) Ihsanullah Ishsan who categorically told the Pakistani authorities that India is providing them shelter, training, finance, and targets to fuel terrorism, insurgency, and instability in Pakistan. Not too old, the former US Secretary of Defense nominee Chuck Hagel officially made a statement about Indian clandestine operations in Pakistan while using Afghanistan's soil. The references would consume the spirit of this study if the Indian National Security Advisor's 'Doval Doctrine' of 'Offensive Defense' is explained which is developed to 
wound Pakistan through non-kinetic warfare particularly sub-conventional war. Hence, India is a state that sponsors, encourages, finances and provides sanctuary to terror groups as its official state policy (Tikhonova, 2017).

\section{Dealing with Bilateral Conflicts:}

The above narration is only to highlight Indian dual face which on the one hand cashes its big geography, demography, economic market and democracy but on the other hand sells false narratives against Pakistan. The most important thing perhaps is not to bring Indian antagonism and controversy into SCO platform. Essential is to understand that other members will definitely be disappointed if Indo-Pak bilateral issues are raised at the forum, which is definitely not meant to play conciliatory role. For example, Indian posture of labeling Pakistan as hub of terrorism is not sellable at this platform neither Pakistan's charge-sheet against India while announcing its non-kinetic warfare particularly state-sponsored terrorism such as Kalbushan Yadev would altogether serve the purpose. Kashmir, Kalbushan Yadev, along with Indian sponsorship to antiPakistan insurgencies could be raised in future but this is not a proper time and place. Right now, SCO is meant for different purposes and as long as remains flourishing. It would automatically expose the negative postures among her members. For instance Pakistan can be remind about the similar controversial situation when in 2017 just before the BRICS summit China and India choose the only correct way not to put "Doklam military conflict" on the table of the meeting.

SCO membership gives Pakistan lots of opportunities to benefit from cooperation on variety of issues with regional stakeholders as well as integration in useful initiatives, programs and economical projects with strategic partners including China and Russia.

The history is the best teacher. So, Pakistan should carefully take lessons. If Pakistan analyzes SAARC problems, it can be assumed that besides other obstacles politicization of the organization was to blame for lack of its effectiveness. The world is already witness to the Indian Prime Minister Narendra Modi decision who due to political reasons refrained from participating in $19^{\text {th }}$ SAARC Summit in Islamabad in 2016 (Panda, 2016). Even in 2018, when Pakistan once again pleaded the case to host the pending SAARC summit, Modi followed his politics of isolating Pakistan and announced unwillingness to participate in the proposed summit (Daily Star, 2018). Following Indian decision at both occasions, representatives from Afghanistan, Bangladesh and Bhutan also refrained from visiting Pakistan.

An international multilateral mechanism always works well until it is not politicized (until it remains apolitical). There are many organizations that qualify to host 'hand twisting' politics of the regional-cuminternational players. Same is true about United Nations (UN), Nuclear Suppliers Group (NSG), International Court of Justice (ICJ) and last but not the least the Organization for the Prohibition of Chemical Weapons (OPCW), where politics of 'power to blame' has been observed since the dawn of $21^{\text {st }}$ century. So politics should be left aside of SCO since it has no space for it in the agenda. Otherwise, the true spirit of this organization as a forum of fare mutual cooperation will be lost somewhere in 'politics to blame'.

\section{Regional Cooperation} Terrorism through RATS:

Development around the globe in terms of lethal weapons, treaties and alliances and international obligations has given birth to different dimensions of warfare mostly covered through terrorism and extremism maneuvers. New terrorist organizations have emerged and are working as proxies in different countries. Violent non-state actors (VNSAs) are gathering support in the form of foreign funding and self created narratives. The condition is that no country in SCO can claim to be safe from terrorism. There are many countries that are covertly supporting terrorism and in order to 
pursue their personal interests and regional dominance and making neighbor as client states. SCO is a strong forum and abidance of norms and laws can be made mandatory to all the member states.

Therefore, in true meanings SCO with all its economic and political achievements has been exceptionally coming along to combat terrorism, which is why the Tashkent based Regional AntiTerrorist Structure (RATS) is leading the consensus among member nations. In fact, RATS as an SCO organization is invested with prime objective to combat three challenges that include extremism, separatism, and terrorism. Knowing the strength of SCO, where four nuclear states are together to install political peace and economic prosperity in the region. This makes SCO not an ordinary but most influential organization of the $21^{\text {st }}$ century geo-political order.

Immediately, after joining the organization Pakistan along with India attended ' $31^{\text {st }}$ Meeting of Council of Regional Anti-Terrorist Structure' held in the month of July 2008 in China. The meeting was convened to discuss issues of regional and international security with that of SCO role in enhancing cooperation to combat terrorism through its member states (Khawaja, 2018).

Pakistan's joining SCO is extremely important in the view of counterterrorism. Members are looking forward to practical cooperation with Pakistan in frames of RATS (Regional Anti Terrorist Structure). RATS in fact has become a strong force which managed to arrest in 2017 more than 500 terrorists and prevented more than 600 bloodbaths (Asia Times, 2018). These achievements clearly indicate huge potential of RATS and the mentioned figures are just the beginning, because Pakistan's experience and intelligence sharing would be definitely useful for SCO.

In August 2018, around 3,000 military personnel participated in a joint drill in Russia which was a joint SCO counterterrorism training mission 'Peaceful Mission 2018'. Troops from Pakistan,
Russia, India, China, Tajikistan, Kyrgyzstan, and Kazakhstan participated, whereas Uzbekistan contributed 10 representatives in the joint military drill. The prime objective of the interaction allowed the participants to share and compare bilateral experiences on strategies, training, and deployment along with logistical support to combat counterterrorism. According to the SCO rules, participation in such activities is obligatory for all members and without any doubt this contributes to security improvement and reducing tensions in the region.

\section{Conclusion:}

SCO was founded with the aim of cooperation in the areas of mutual interregional activities on countering terrorist acts, separatism and extremism and to strengthen relations among member states to promote cooperation in political affairs, economics and trade; the organization in $21^{\text {st }}$ century would help both Pakistan and India to mend their ties and uphold the spirit of the SCO. Since, the establishment of SCO, the organization has given great priority to fight against terrorism, separatism and extremism which posses a real threat to security of all member states. Tashkent based Regional Anti-Terrorism Structure (RATS) has been established in this backdrop and marks one of the rare times when India and Pakistan conducted a joint military exercise immediately after joining the organization. It is important to highlight that cooperation in the field of counter terrorism between Pakistan and India has never been found before in the entire political history. RATS provided the exceptional platform to both the states.

Possessed with great potential, Pakistan could easily achieve an active and productive role in the Shanghai Cooperation Organization. Therefore, it should understand the scope and prosperity associated with Shanghai Cooperation Organization which it must avail for the benefit of its own nation and larger community. Time to invest to expose Indian dual face shall be considered 'wastage', 
rather identifying common avenues of bilateral cooperation with responsible SCO member states shall be the opportunity. Pakistan must lead into this domain and be the first South Asian states fully benefiting from the organization. Islamabad must use SCO to come closer to Russia in all organizational priorities as well as on bilateral fronts. The nation is exposed to new century, sticking to its past and antagonist neighbor is disguise rather blessing.

References

[1] Ahmed, A. (2017). Pak-Russia Relations and Future Prospects. Defence Journal, 20(7), 14.

[2] Ahmed, S. (1999). Pakistan's nuclear weapons program: Turning points and nuclear choices. International Security, 23(4), 178-204.

[3] Bailes, A. J., Dunay, P., Guang, P., \& Troitskiy, M. (2007). The Shanghai cooperation organization. SIPRI.

[4] Bertrand, N. (2016). NATO's Second Largest Military Power Is Threatening a Dramatic Pivot to Russia and China. Business Insider.

[5] Bin, Y. (2018). TALES OF TWO FRIENDS, TWO SUMMITS AND TWO DRILLS. Comparative Connections: A Triannual EJournal on East Asian Bilateral Relations, 20(2).

[6] Blanchard, B. (2018). China fails to get Indian support for Belt and Road ahead of summit. Retrieved January, 9, 2019.

[7] Bose, S. (2009). Kashmir: Roots of conflict, paths to peace. Harvard University Press.

[8] Bhan, M. (2014). MORALITY AND MARTYRDOM: DAMS,"
DHARMA", $\quad$ AND THE CULTURAL POLITICS OF WORK IN INDIAN-OCCUPIED KASHMIR. biography, 191-224.

[9] Fulton, J. (2018). Could the SCO Expand Into the Middle East?. The Diplomat.

[10] Hilali, A. Z. (2017). US Pakistan relationship: Soviet invasion of Afghanistan. Routledge.

[11] Len, C. (2007). Energy security cooperation in Asia: an ASEAN-SCO energy partnership?'. Energy perspectives on Singapore and the region, 165-169.

[12] Organisation, S. C. (2009).

Brief Introduction to the Shanghai Cooperation Organisation.

[13] Pathak, M. K., Jha, S. S., \& Rai, S. (2018). A case reported under POCSO act and murder. Journal of Punjab Academy of Forensic Medicine \& Toxicology, 18(2), 8793.

[14] Pattanaik, S. S. (2016). Subregionalism as new regionalism in South Asia: India's role. Strategic Analysis, 40(3), 210-217.

[15] Sargana, T. H. (2018). Pakistan's Policy Postures towards Shanghai Organization. Defence Journal, 21(10), 13-19.

[16] Sharaf, S. S. (2017). South Asian strategic muddle.

[17] Shekhar, S. (2017). Water security: Need for paradigm shift. In India's National Security (pp. 290-308). Routledge India.

[18] Singh, S. (2018). Changing Sino-Indian Relations: Implications for South Asia. IJEAS: The International Journal of East Asian Studies, 7(1), 48-58.

[19] Jabeen, M., \& Mazhar, M. S. (2011). Security game: SEATO and CENTO as instrument of economic and military assistance to encircle Pakistan. Pakistan Economic and Social Review, 109-132. 
[20] Khoo, N. (2011). Collateral damage: Sino-Soviet rivalry and the termination of the Sino-Vietnamese alliance. Columbia University Press.

[21] Wolf, S. (2016, June). The China-Pakistan Economic Corridor:
An assessment of its feasibility and impact on regional cooperation. In SADF Comment, South Asia Democratic Forum (SADF), Brussels, Belgium. 